\title{
Mitochondrial dynamics in degenerative disease and disease models
}

\author{
Eric M. Merzetti and Brian E. Staveley* \\ *Correspondence: bestave@mun.ca \\ Department of Biology, Memorial University of Newfoundland, 232 Elizabeth Avenue, St. John's, Newfoundland and Labrador, \\ A1B 3X9, Canada.
}

\begin{abstract}
Degenerative diseases cause the breakdown or destruction of a cell or group of cells over a period of time, leading to an array of physical or cognitive symptoms including impaired motor skills, memory loss and dementia. Often, degenerative diseases have been characterized as afflictions of the elderly but earlier onset forms of these diseases have been linked to genetic dysfunction. Mutant forms of genes often lead to the breakdown of the cell via interference with internal pathways involved in the removal of impaired cellular components and energy production. Mitochondria are dynamic organelles involved in cellular energy production and in intra-cellular signalling leading to cell death. The proper function and upkeep of these organelles is essential to maintaining a healthy cellular environment and preventing accumulation of harmful oxidative free radicals. Breakdown and improper functioning of mitochondria has been linked to the onset of a number of diverse neurological diseases including Alzheimer Disease, Huntington Disease, Parkinson Disease, Multiple Sclerosis, retinal abnormalities and muscle neuron linked motor impairment. In this review, we examine the role of mitochondria in degenerative disease and highlight common mechanisms of disease progression as well as potential targets for future therapeutic approaches.
\end{abstract}

Keywords: Neurodegenerative, parkinson disease, alzheimer disease, sclerosis, huntington disease, myositis

\section{Introduction}

Mitochondria are essential cellular organelles that act as the "power plants" of the cell to provide energy in the form of Adenosine triphosphate (ATP) by means of the Electron Transport Chain (ETC). They are key components in mechanisms of cell growth, cell proliferation and apoptosis. Due to their inability to derive sufficient energy through glycolysis, neuron-rich tissues rely greatly upon mitochondria when compared to those that possess lower energy needs [1]. Since mitochondria are involved in such diverse and important cellular functions; it is not surprising that the breakdown or dysfunction of mitochondrial processes may result in a number of disorders or diseases. Many of these disorders are caused by defective degradation of damaged or non-functional mitochondria and a subsequent lack of de novo synthesis of new replacement mitochondria [2]. We will highlight the genes and pathways involved in mitochondrial degenerative disease in order to determine their potential for future study as targets for chemotherapeutic treatment and disease modelling.

\section{The evolution of a cellular power plant The origin of mitochondria}

Mitochondria are unique organelles due to their double membrane structure and conserved organelle specific DNA (mtDNA). Evolution of these organelles through Endosymbiosis is theorized to have involved the amalgamation of microorganisms through the ingestion and assimilation of an aerobic microorganism by an anaerobic one [3]. Sequence comparisons of mitochondrial DNA have determined their origins to stem from a single a-proteobacterium [4]. Over the course of evolutionary history mtDNA has evolved in a speciesspecific manner, hinting that selective pressures may drive the repositioning of genes from the mtDNA to the genomic DNA [5]. The mtDNA codes for many important and necessary genes, although this pressure has resulted in mitochondrial genomes being much smaller in size than they were originally. Most of the retained genes function within the ETC of respiration at the mitochondrial inner membrane [6]. There are three main theories that seek to explain the conservation of mtDNA. The first is that genes encoded for and translated within the mitochondria produce hydrophobic proteins which may be difficult to import into the inner membrane after translation outside of the organelle [7]. Alternatively, differences in codon usage between the genomic machinery and mitochondrial mechanisms may cause difficulties in proper protein translation, making it necessary for these proteins to be synthesized within the mitochondria. A third theory postulates that mitochondrial DNA is conserved as locally regulated expression of these integral electron transport genes may be important for metabolic control [8]. It is likely that the true rationale for the continued conservation of mtDNA encompasses aspects of all three theories. 
Merzetti and Staveley Neuroscience Discovery 2013,

\section{Energy and reactive oxygen species production}

Mitochondria produce chemical energy in the form of ATP by harnessing the gradient created through movement of electrons from an electron donor such as Nicotinamide Adenine Dinucleotide (NADH) to an electron acceptor such as oxygen, in a process known as oxidative phosphorylation. This process is conducted by five protein complexes (complexes $\mathrm{I}-\mathrm{V}$ ) located within the inner membrane of the mitochondria and results in the formation of two water molecules. Complex I (NADH coenzyme Q reductase) and Complex II (succinate dehydrogenase) both accept incoming electrons from $\mathrm{NADH}$ and Flavin Adenine Hydrogen Dinucleotide $\left(\mathrm{FADH}_{2}\right)$ respectively. Both of these complexes pass electrons to coenzyme Q (ubiquinone) where they are ferried to Complex III (cytochrome bc $c_{1}$ ). From Complex III the electrons are transferred to cytochrome C then to Complex IV (cytochrome c oxidase) and from this complex to oxygen to create water [9]. Three of these complexes (Complexes I, III and IV) pump protons into the inter-membrane space to create a gradient which is responsible for generating the mitochondrial inner membrane potential. This proton motive force is then harnessed by complex V (ATP synthase) to facilitate the synthesis of ATP from ADP and $P$.

During the course of this process it is possible for electrons to leak out of this electron transfer cascade and create potentially toxic oxygen free radicals. Complexes I and III have been determined as the two most likely sites for this leakage to occur $[10,11]$. These free radicals have the capacity to disrupt a number of cellular processes and to alter DNA sequences; this is especially dangerous due to the close proximity between mtDNA and free radicals formed within the mitochondria. To combat these potentially negative effects, many proteins, including the Superoxide Dismutase (SOD) family, counteract the formation of these Reactive oxygen species (ROS). SODs are metalloproteins that catalyze the conversion of superoxide into oxygen and hydrogen peroxide [12]. There are three distinct types of SOD enzymes: SOD1 and SOD3 operate in the cytoplasm and extracellular matrix, respectively, and contain copper and zinc as their metallic components [13]. SOD2, like SOD1 and SOD3, is encoded by the nuclear genome but following synthesis, is transported across the outer and inner mitochondrial membrane to function in the matrix. SOD2 operates by means of a manganese metallic enzymatic component and is the only SOD that functions within the mitochondria [14]. Proper function of all three SOD proteins is essential for regular cellular homeostasis.

Reactive oxygen species negatively impact the cell in two distinct yet equally important ways. The first is by directly interacting with and modifying cellular components, leading to change or loss of function. The second is by altering the reduction-oxidation (REDOX) state of proteins involved in signalling pathways and leading to altered activation of downstream targets [15]. Although the formation of ROS is generally considered to be harmful in terms of cell function and well being, ROS function as signalling molecules that are necessary for proper cellular control and upkeep [16] One of the most important and diverse molecules involved in intracellular cycling, hydrogen peroxide $\left(\mathrm{H}_{2} \mathrm{O}_{2}\right)$, is formed as a result of electron leakage. $\mathrm{H}_{2} \mathrm{O}_{2}$ is a by-product of SODmediated removal of superoxide anions but may be induced via a number of other cellular mechanisms including NADPH oxidase [17]. $\mathrm{H}_{2} \mathrm{O}_{2}$ is a relatively stable molecule and acts as a signalling molecule in pathways of cell proliferation, differentiation, cell growth and apoptosis $[18,19] . \mathrm{H}_{2} \mathrm{O}_{2}$ works mechanistically via the oxidation of thiols, and may result in an irreversible reaction. A class of enzymes known as catalase peroxidases function to breakdown $\mathrm{H}_{2} \mathrm{O}_{2}$ molecules into water and oxygen and antioxidant defence mechanisms have been found to be up-regulated in the presence of increased $\mathrm{H}_{2} \mathrm{O}_{2}$ [20]. Coordination of intracellular $\mathrm{H}_{2} \mathrm{O}_{2}$ levels is largely reliant on mitochondria, aberration in this regulation can lead to wide encompassing negative consequences for cellular health.

\section{Control of mitochondrial upkeep and turnover Mitochondrial creation and destruction}

There are a number of mechanisms through which proper mitochondrial function is maintained. Some signalling pathways are involved in the diagnosis, repair and breakdown of organelles while other methods are exploited to produce new mitochondria via biogenesis. The delicate balance between organelle biogenesis and turnover not only helps to prevent the squandering of important cellular materials, but leads to proper disposal of potentially harmful, abnormally functioning organelles. Thus, it is not surprising that dysfunction of genes involved in any number of these upkeep and turnover pathways has been linked to the progression of multiple degenerative diseases.

The peroxisome Proliferation activated Co-receptor Gamma (PCG) family of genes have been found to regulate de novo mitochondrial synthesis. PGC-1 $a$ and $P G C-1 \beta$ are involved in mitochondrial biogenesis within various tissues including the liver and brain, and are up-regulated under conditions requiring increased energy production. PGC-1a-Related Coactivator $(P R C)$ is linked to biogenesis of mitochondria, but unlike other PGC-1 family members does not vary in abundance based on the energetic needs of the cell $[\mathbf{2 1}, \mathbf{2 2}]$. PGC-1 proteins work by promoting transcription of Nuclear Respiratory Factor-1 (NRF-1) which leads to de novo mitochondrial synthesis. In a parallel pathway, Nuclear Respiratory Factor-2 (NRF-2) contributes to this de novo synthesis. Together, the NRF genes have been found to coordinate expression of all ten electron transport subunit components coded for by the mtDNA [23]. Expression of $P G C-1$ family and NRF family genes have both been linked to multiple regulators of cell growth, and proliferation.

\section{Mitochondria and apoptosis}

Apoptosis is the process of programmed cell death; a mechanism 
responsible for removing cells via specific pathways for the purpose of increasing the overall fitness of an organism. Due to the high incidence of ROS leakage and consequent genomic damage found within mitochondria, there are organelle specific mechanisms in place for apoptosis to occur, thereby combating potentially harmful components from spreading to nearby cells. These mechanisms generally involve permeabilization of the outer and/or inner mitochondrial membrane and release of internal components into the cytosol. Both the Mitochondrial Outer Membrane Permeability (MOMP) and Mitochondrial Permeability Transition Pore (PTP or MTP) have been implicated in this release.

The release of the signalling molecule cytochrome $C$ triggers a caspase-activated cascade in the cytosol of the host cell, leading to apoptotic destruction via association with Apoptotic protease-activating factor 1 (Apaf1) [24]. In addition to cytochrome $C$ activation of the caspase cascade, Apoptosis Inducing Factor (AIF) is released from the intermembrane space and translocates to the nucleus where it binds to DNA and facilitates fragmentation [25]. This process has been found to be mediated by $\mathrm{Bcl}-2$ family pro-apoptotic proteins $\mathrm{Bcl}-2$ associated $\mathrm{X}$ protein (Bax) and $\mathrm{BCl}-2$ homologous antagonist killer (Bak) which form the channel for release of intra-organelle components by MOMP [26]. Both Bax and Bak are activated by two other pro-apoptotic $\mathrm{BCl}-2$ proteins, $\mathrm{BH} 3$ interacting domain death agonist (Bid) and $\mathrm{BCl}-2$ interacting mediator of cell death (Bim) [27]. Upon activation Bax translocates to the mitochondrial membrane where Bak is prelocalized due to interaction with the membrane bound Voltage Dependent Ion Channel 2 (VDAC-2) [28]. Activated forms of Bax and Bak then form a pore in the membrane of mitochondria allowing pro-apoptotic factors to be released.

\section{Mitochondrial movement and dynamics}

The ability of mitochondria to respond to changes in cellular energy requirements, starvation or dysfunction is necessary for continued organelle health. The processes of fusion and fission provide the means of adapting to these changes through the formation of "new" mitochondria or the assimilation of multiple mitochondria into a single organelle. The process of fission is mediated by Drp1, a cytosolic protein that is recruited to the outer membrane by Mid49, Mid50 and Mff and functions by pinching the membrane together and allowing for separation of internal components without leakage [29]. This process occurs most often at sites where the membranes of mitochondria and endoplasmic reticulum (ER) make contact, and the inner and outer membranes each have specific factors that aid in this process; the outer membrane fission is mediated by Mfn 1 and $\mathrm{Mfn} 2$ membrane anchored proteins while the inner membrane is mediated by Opa1 activity [30]. The process of mitochondrial fusion functions to protect against harmful aggregation of mitochondrial mutations by allowing a mechanism of organelle complementation [31]. By this process, two mitochondria are able to fuse together and share RNA and protein components, providing protection against mutation of the mtDNA and ensuring the proper function of each individual organelle. Fusion is increased under conditions of starvation and works to ensure that mitochondria are not the active targets of cellular catabolism, thereby allowing energy production via oxidative phosphorylation to continue unhampered under extreme conditions [32]. It has been hypothesized that fission and fusion may work cooperatively to remove damaged material from organelles by facilitating fusion of impaired mitochondria with healthy ones. Such a mechanism would serve to selectively remove the damaged components via asymmetric fission, where they will eventually be targeted for lysosomal degradation [33]. Together, these processes work to provide a healthier mitochondrial population and conserve cellular energy by providing more efficient oxidative phosphorylation and organelle maintenance.

The movement of mitochondria within cells is an important process that must respond to cellular energy requirements and is especially significant in specialized cells including neurons. The movement of organelles is dependent on force generating motor proteins that allow interaction with microtubules or actin filaments [34]. Kinesin-1 is the primary factor that influences mitochondrial anterograde movement in neurons, and this process is limited by $\mathrm{Ca}^{2+}$ concentration by the GTPase Miro [35]. A high concentration of cytosolic $\mathrm{Ca}^{2+}$ will halt this movement from occurring, potentially as a sensor of organelle dysfunction. Retrograde movement is mediated by the Dynein-Dynactin complex which connects to mitochondria via the Huntington Associated Protein (HAP) [36]. Damage to any of the proteins involved in organelle transport may lead to an aggregation of damaged organelles and cell death.

\section{Mitochondria and degenerative disease}

Degenerative diseases are defined as afflictions that present a deterioration of a tissue or group of cells over a period of time. Types of degenerative disease are generally split into two main groups. The first, neurodegenerative disease, affects many functions through damage to the brain and neurons. The second type, muscle degenerative disease, functions by gradual disruption of muscle function in different parts of an organism. Many categories of neurodegenerative disease also result in muscle degeneration or lead to similar phenotypes. Degenerative diseases are chronic and in many cases treatment options seek to slow symptoms of the disease and do not attempt to combat the initial source or cause of those symptoms.

\section{Degenerative disease and proteostasis}

The balance of proteins within a cell or organelle is necessary for healthy cell function. Accumulation of harmful protein aggregates is a hallmark of many different forms of degenerative disease including Alzheimer disease, 
Merzetti and Staveley Neuroscience Discovery 2013,

http://www.hoajonline.com/journals/pdf/2052-6946-1-8.pdf

doi: $10.7243 / 2052-6946-1-8$

Parkinson disease and sporadic Inclusion Body Myositis [37]. Impaired intracellular dynamics or breakdown of intracellular proteosomal machinery and improper processing and destruction of these protein aggregates ultimately leads to impaired mitochondrial function, increased free radical generation and eventual cell death.

\section{Alzheimer disease}

Alzheimer Disease (AD) is a progressive neurological disorder characterized by a degenerative breakdown of neurons in the cortex and hippocampus of the brain [38]. AD is the most common late onset neurodegenerative disease and, although the majority of cases are apparently sporadic in occurrence, mutations in three genes have been found to be directly implicated with neuronal breakdown. These mutations are found in genes encoding the Amyloid Precursor Protein (APP), and the two catalytic $\gamma$-secretase subunits Presenilin-1 (PSEN-1) and Presenilin-2 (PSEN-2), and lead to the earliest and most severe cases of $A D$ [39]. The degeneration of neurons in $A D$ is catalyzed by harmful presence of two separate protein entities: the first is an aggregation of a hyper phosphorylated form of the microtubule stabilizing protein Tau [40], while the second is the accumulation of the protein Amyloid-Beta (AB) [41]. In some advanced forms of AD both of these forms of protein aggregates have been found.

APP under normal physiological conditions modulates neuronal growth and plasticity through activation by $\mathrm{Y}$-secretase. Amyloid-Beta is a derivative of APP that is posttranslationally cleaved by either PSEN-1 or PSEN- 2 to remove the C-terminal trans-membrane domain [42]. The Amyloid cascade hypothesis of AD progression states that an over abundance of $A \beta$ leads to an increase in the oxidative stress of the cell [43]. This cascade leads to changes in intracellular Redox state which is believed to result in the hyperphosphorylation of some cellular proteins including Tau. The pathogenesis of Tau protein aggregates occurs through paired helical fragments termed "Tau inclusions". These insoluble protein aggregates are a hallmark of disease and cause a number of problems in neuronal tissues both by preventing the native functions of Tau, as a necessary factor in microtubule stabilization, and by disrupting other cellular processes [44]. Diseases attributed to the accumulation of hyperphosphorylated Tau protein are termed "Taupathies".

In mitochondria, $A \beta$ binding Alcohol Dehydrogenase (ABAD) has been found to bind directly to $A \beta$ and increase the production of free radicals within mitochondria [45]. A bi-product of this reaction is acrolein which lowers activity of key components of the TCA cycle and binds with mtDNA preventing interactions and altering activity. Additionally $A \beta$ has been implicated in impairing the function of SOD2 in the matrix of mitochondria, thus diminishing the internal defense against superoxide oxidation and leading to a further increase in ROS formation [46]. The increase in ROS and decrease in metabolic rate that occurs as a result of an import of $A \beta$ in mitochondria gradually leads to reduced energy production and eventual cell death.

A second hypothesis relating to the importance of mitochondria in AD has recently emerged. The Mitochondia Associated Membrane hypothesis proposes that the proximity of the ER to the mitochondria is a key factor in AD pathogenesis [47]. This hypothesis postulates that a decreased distance between the membranes of the ER and the mitochondria results in altered metabolism and redox states of both organelles and leads to the hyper phosphorylation of Tau and improper APP processing. Although the aggregation of protein plaques has been cited as the direct cause of $A D$, there is a body of evidence to suggest that these consequences are a function of initial mitochondrial dysfunction [48]. Although no specific mtDNA mutations have been linked to AD [49], an initial dysfunction of mitochondrial function causing a change in redox state and oxidative consequences could be the trigger to all of these processes in sporadic AD.

\section{Parkinson disease}

Parkinson Disease (PD) is a common and progressive neurological disease that is estimated to afflict $1 \%$ of all individuals worldwide over the age of 60 years [50]. Clinical symptoms include resting tremor, bradykinesia, rigidity and postural instability. Additional difficulties may include loss of memory and depression [51]. These symptoms are caused by diminished levels of dopamine availability in the striatum of the brain, and are characterized by the accumulation of harmful protein aggregates known as Lewy bodies within the neurons of the substantia nigra pars compacta [52]. The eventual dysfunction and breakdown of these neurons is responsible for the symptoms and pathology of PD [53]. A higher mtDNA mutation rate is present in dopaminergic neurons affected by PD compared to wild type controls [54]. Pathology traces directly to mitochondrial dysfunction and cell destruction in these neurons.

A number of genes from human tissue that show importance in mitochondrial function and PD have been identified. The SNCA gene encodes for the a-synuclein protein, the primary component of Lewy bodies [55]. Lewy bodies can be the result of a mutant form of SNCA leading to an accumulation of protein aggregates within the inner membrane of mitochondria. These protein aggregations disrupt components of the ETC resulting in a higher incidence of oxidative stress [56]. Accumulation of Lewy bodies has been found to be associated with malfunctioning proteasome function. Parkin is a component of a multiprotein E3 ubiquitin ligase that promotes the ubiquitination and subsequent destruction of cellular proteins [57]. Mutations of the parkin gene result in the degeneration of dopaminergic (DA) neurons, most likely by allowing the aggregation of multiple dysfunctional mitochondria that eventually lead to overall cell death [58]. PTEN induced putative kinase 1 (PINK1) is a serine/threonine-protein kinase that can act to recruit Parkin to damaged mitochondria [59]. Similarly to Parkin, 
mutations in PINK1 lead to degeneration and dysfunction of DA neurons [60]. These proteins act in concert to remove any damaged or dysfunctional mitochondria that may be present. Mutation of either of these genes negates the cell's ability to target and remove dysfunctional mitochondria, which in turn leads to cell death.

Transcriptional regulation of $P G C-1 a$, linked to the pathology of PD, is controlled by a negative regulator the "Parkin interacting substrate", or PARIS. When PARIS is active, it binds to the upstream region of the $P G C-1$ a gene to prevent transcriptional activity. In turn, this blocks the occurrence of mitochondrial biogenesis [61]. Interestingly, PARIS is degraded following ubiquitination by Parkin [62]. Therefore, Parkin appears to be a master regulator of both mitochondrial biogenesis and mitochondria autophagy in human cells and a key component in the pathogenesis of PD.

\section{Sporadic Inclusion-body Myositis}

sporadic Inclusion-Body Myositis (s-IBM) is the most common muscle degenerative disease of the elderly. Hallmarks of this disease include gradual weakening and dysfunction of muscle tissue, eventually leading to severe disability and wheelchair dependency [63]. Muscle fibre degeneration results from an intramuscular accumulation of harmful protein aggregates implicated in the pathogenesis of multiple neurodegenerative diseases including: $A \beta, a-$ synuclein, and $p$-Tau [64]. The aggregation of these protein clusters in affected cells causes a number of harmful consequences.

The mechanisms of infection are very similar to those manifested in both $A D$ (in the case of $A \beta$ and $p$-Tau) and in $P D$ (in the case of $\alpha$-synuclein) [65]. One of the most puzzling aspects of s-IBM pathogenesis is the apparent dysfunction of proteosomal systems in removing harmful protein aggregates. Proteosome subunits appear to be inactivated in muscle cells containing these proteins, and lysosome function is impeded leading to the formation of large autophagosomal vacuoles [66]. Within these vacuoles, new protein aggregates form that may then cause increased cellular disruption and damage [67]. Protein aggregates may disrupt the mitochondria either directly by association within the intermembrane space, or indirectly by altering cellular processes such as calcium transport leading to impaired cellular respiration, oxidative stress increase and eventual cell death.

\section{Therapeutic approaches to proteostatic disorders}

Pharmacological and therapeutic approaches to dealing with imbalances in protein abundance or harmful aggregate formation fall into two main areas of concentration. The first addresses the observed breakdown of mitochondrial dynamics leading to unhealthy organelles and protein buildup. Pharmacological compounds such as the Drp1 inhibitor "resveratrol" [68] and M1 hydrazone [69] promote fission and fusion processes respectively but have yet to be tested as human therapeutics. The second addresses improper functioning mitochondrial quality control. Impaired Parkin or PINK1 function has also been marked as a potential target for therapeutic intervention as improved functioning of these genes would lead to more efficient turnover of damaged mitochondria, a lowered level of oxidative stress and less overall cellular stress. Intra-organelle components are able to sense incorrectly folded proteins by manner of a network known as the unfolded protein response (UPR) [70]. Deciphering the mechanism of the UPR response including Heat Shock Factor 60 and the protease ClpP and how they are regulated may lead to potential therapeutic targets to stimulate for proper removal of protein aggregates [71]. Recent work has found that Activating Transcription Factor Associated with Stress-1 (ATFS-1) may initiate the cascade leading to UPR activation [72], although no direct mammalian therapeutic target of this system has been identified.

\section{Degenerative disease and aberrant gene function}

The mutation of genes involved in essential cellular processes such as free radical removal, cellular trafficking and energy production leads to degenerative disease phenotypes and cellular destruction. Huntington Disease, Multiple Sclerosis, Amyotrophic Lateral Sclerosis, Kearns-Sayre Syndrome, Leber's Hereditary Optic Neuropathy and Age Related Macular Degeneration are all specific diseases resulting from aberrant gene function [73]. Although the impaired genes in each case are unique to one another, the mechanism of disease often follows a similar progression stemming from reduced efficiency and increased oxidative stress eventually leading to cell death.

\section{Huntington disease}

Huntington Disease (HD) is a progressive neurodegenerative disease that leads to muscle defects and cognitive decline, all stemming from alterations to a single gene, Huntingtin $(\mathrm{Htt})$. Mutation of this gene results in the incorporation of additional glutamine residues and elongation of a polyglutamine chain within the protein is responsible for development of the disease [74]. Mutant $\mathrm{Htt}$ is an autosomal dominant mutation but two mutant gene copies can result in increased severity and earlier onset of the disease [75]. Medium-sized spiny striatal projection neurons are the first tissues targeted, however as the condition progresses other areas of the brain, including the Basal Ganglia, are affected causing additional symptoms [76]. There has been much discussion over the principle site of disease pathology within the cell. Evidence may suggest that mitochondrial dysfunction is a hallmark of disease, but whether or not this stems from an initial breakdown of organelle function or is a secondary effect of other dysfunction is currently undetermined.

The cascade of consequences associated with HD begins with a lowered metabolic rate and progresses into an increase of ROS and caspase activation [77]. While these are definitive hallmarks of mitochondrial dysfunction, the mechanism 
Merzetti and Staveley Neuroscience Discovery 2013,

of this breakdown has not yet been identified and studies of patient brain activity in the early stages of HD indicate that the lowered metabolic rate does not occur until later in disease progression [78]. Mutant $\mathrm{Htt}$ protein ( $\mathrm{mHtt}$ ) has been shown to disrupt the transcriptional regulation of TATA binding proteins and the transcription factor Specificity 1 (Sp1) leading to the dysregulation of nuclear transcription genes including those that code components of the mitochondria [79]. Two genes that are influenced by this dysregulation are PGC-1 $a$ and Transcription Factor A Mitochondrial (TFAM), both significant factors in the upkeep and function of new and existing mitochondria [80].

Additionally, there is some evidence to support that $\mathrm{mHtt}$ may localize to the outer mitochondrial membrane and prevent the proper function of MPT control and organelle plasticity through fusion and fission processes [81]. Taken together, it is clear that mitochondrial function and destruction is a vital and central process in the middle to later stages of HD.

\section{Multiple sclerosis}

Multiple Sclerosis (MS) is a progressive early onset neurodegenerative disease that, unlike most neurodegenerative diseases, strikes patients in early adulthood, usually before the age of thirty. MS pathology progresses in two basic forms; the first is a stereotypical model of neurological disease that involves symptoms that become increasingly severe over time, whereas the second form involves a relapse-andrecovery model in which the patient shows severe symptoms followed by brief periods of recovery [82]. Both forms of disease eventually lead to severe loss of motor control and mental impairment due to neuronal dysfunction. The most common theory concerning MS pathology is based on an autoimmune model in which components of myelin are presented as antigens, with the resulting cellular immune response acting to target these myelin sheaths for destruction [83]. Removal of the myelin sheath of an axon prevents signal transduction, abrogates functional activity and leaves a characteristic abnormal structure known as a plaque. There are additional factors that contribute to disease progression in MS that may make for appropriate therapeutic targets in disease prevention or symptom control.

Mitochondria have been implicated in a number of potential factors contributing to MS. Mutation of mtDNA has been linked with disease risk and mutant forms of ETC complex I and Mitochondrial Uncoupling Protein 2 (UCP2), a component of proton transport responsible for the maintenance of membrane potential, have been correlated with increased MS occurrence [84]. Mitochondrial DNA deletion has been shown to be a causative agent of disease in specific cases [85]. An increase of intra-organelle $\mathrm{Ca}^{2+}$ and conditions of hypoxia are commonly found in MS neuronal cells. The reduced amount of ATP production caused by dysfunction of the enzymes within the ETC results in diminished activity of the $\mathrm{K}^{+}, \mathrm{Na}^{2+}$ exchange pump ATPase activity. This leads to an influx of $\mathrm{Na}^{2+}$ and ultimately, membrane depolarization [86]. In turn, depolarization and increased intra-organelle $\mathrm{Na}^{2+}$ causes an influx of $\mathrm{Ca}^{2+}$, leading to cellular damage while simultaneously removing both the action potential of the cell alongside the nerve transmission function [87]. Another consequence of depolarization is activation of the MPT via modulation of Cyclophilin D (Cy PD), subsequently releasing apoptotic factors while increasing ROS production. Studies in mice have shown that a decrease in Cy PD may raise cellular resistance to oxidative stress and prevent the cellular destruction invoked by this membrane change, making it a potential target for therapeutic intervention [88]. In addition to these observations, increased accumulation of APP has been observed in MS plaques, to suggest a potential link to ER and the mitochondrial associated membrane as proposed for $A D$ [89]. The origin of MS pathology has not been directly correlated to mitochondrial dysfunction but progression of the disease influences and perhaps is influenced by mitochondrial breakdown.

\section{Amyotrophic lateral sclerosis}

Amyotrophic Lateral Sclerosis (ALS) is a progressive degenerative disease of the motor neurons. Early symptoms include muscle weakness, stiffness or numbness over time, and individuals frequently experience difficulty moving, speaking or swallowing. Upwards of $90 \%$ of diagnosed cases of ALS are sporadic in origin with $10 \%$ of cases originating from heritable mutations [90]. A subset of these mutations has been linked to genes encoding proteins that interact either directly or indirectly with the mitochondria.

The most studied gene linked to ALS is Superoxide Dismutase 1 (SOD1). It has been found that a mutant form of SOD1 directly affects motor neuron dynamics, including the transport of mitochondria within the neuronal cell [91]. An increase of SOD1 expression correlates with the up-regulation of over 50 mitochondrial proteins including Mfn2, indicating that SOD1 does not solely function in the destruction of ROS alone, but acts as a feedback regulator of fusion and membrane potential within mitochondria [1]. Mutant SOD1 protein is partial to misfolding and translocates into the mitochondrial intermembrane space [92]. The presence of this mutant SOD1 protein has been shown as a necessary component for causing cell death in ALS models of disease [93]. Currently, it is unknown if this affect is a consequence of enhanced oxidative stress of the organelle, abrogating functioning protein cascades responsible for axonal movement or by disruption of membrane potential, which would cause the release of apoptotic factors.

Three other mutations have been implicated in human ALS pathogenesis. Vesicle-Associated membrane Protein $B$ (VAPB) is a protein involved in calcium homeostasis and associates with proteins located in the MAM between the ER and mitochondria. Mutant forms of this protein cause increased oxidative stress and cell death [94]. TAR DNA binding 
protein (TDP-43) binds to both DNA and RNA and regulates RNA metabolism and pre-mRNA splicing [95]. Loss of this gene activity leads to aggregation of the mutant protein in the cytosol of functional cells, potentially in the area of previously functional mitochondria [96]. Although no further testing has been carried out in human subjects, experiments conducted using a yeast model suggest that these aggregates contribute to increased oxidative stress and cell death, while introduction of mutated TDP-43 from humans into mice leads to mitochondrial depletion in motor neurons $[97,98]$. Similarly, a mutant form of the RNA binding protein Fused in Sarcoma (FUS) linked to ALS has been found to induce mitochondrial shortening and cytoplasmic aggregation in a mouse model of disease [99]. Deletion of mtDNA have been implicated in ALS disease progression [100]. Although it is not clear where the initial site of disease pathology begins, the break down and disruption of mitochondria is clearly an important step in ALS disease progression.

\section{Retinal disease}

Due to the high energy requirements associated with the optic nerve and cells of the retinal pigment epithelium, mitochondria have been implicated in a number of diseases associated with vision loss and metabolic dysfunction of these tissues [101]. Kearns-Sayre Syndrome (KSS) and Leber's Hereditary Optic Neuropathy (LHON) have been linked to specific mutations in the mtDNA and result in involuntary movements of the eyelid, peripheral vision loss, impaired vision and in some forms MS like symptoms in later stages $[102,103]$. Onset of each of these conditions is between 10 to 30 years of age and symptoms develop gradually. KSS pathology occurs by systematic and degenerative removal of the neurons of the retinal pigment epithelium and is marked by a decrease in glucose levels, to suggest dysfunction of the ETC and subsequent increase of ROS as a mechanism of disease [104]. LHON shows a marked degeneration of retinal ganglion cells and their corresponding axons. The mechanism of disease is thought to involve one of two processes related to mitochondrial function; the first is a potential impairment of mitochondrial dynamics and movement resulting in a lack of mitochondria at specific regions of the neuronal cell [105], the second is by sensitising the cell to apoptosis via an increased concentration of ROS [106]. It is likely that these two factors work in concert to cause disease etiology, rather than each acting individually.

Age Related Macular Degeneration (AMD) and Glaucoma are two degenerative retinal diseases that have been linked to specific mutations in mtDNA. Unlike KSS and LHON, these diseases are often found only in elderly populations of 50 years of age and above. Glaucoma pathology is attributed to an increase in intra-ocular pressure causing death of the retinal ganglion cells [107]. Increased hydrostatic pressure has been found to incite an increase in mitochondrial fission processes and oxidative stress within the cell $[108,109]$. Coupled with this is a characteristic decrease in ATP synthesis and respiration which eventually lead to activation of pathways involved in cell death [110]. AMD primarily affects the central portion of the retina, the macula, and is the primary cause of elderly blindness. The main cause of disease progression in AMD is a buildup of debris (known as drusen, dry AMD), or the growth of blood vessels (wet AMD), both of which occur between the retina and choroid [111]. Pathogenesis of AMD originates from the accumulation of mitochondrial mutations and oxidative stress over time [112]. The heavy stress imparted upon mtDNA due to free radicals from the ETC is a potential starting point for mutation in tissues with high energy requirements, and retinal disease is a prime example of such consequences.

\section{Additional diseases}

Mitochondria influence a substantial number of cellular processes through the regulation of energy production; as such they influence a number of diseases that may display degenerative pathologies. Diabetes mellitus occurs in some individuals through mechanisms that are similar to the causes of $A D$, and may arise from an initial change in cellular oxidation state, thereby resulting in a lack of energy and leading to cell death [113]. Heart function relies upon mitochondria to provide energy in the form of ATP, and changes in mitochondrial function can lead to decreased activity and eventually to fatality. Infection with Rabies virus has been found to directly cause mitochondrial dysfunction and oxidative stress leading to cellular destruction and a degenerative phenotype [114]. In many forms of cancer, mitochondria are required to provide "retrograde" signals to the nuclear machinery, activating pathways and adapting the cell to the needs of the cancer cell. In this case mitochondria are not inactive but actually function at a higher rate to provide additional energy for disease progression [115]. In addition to having a potential role in many serious physiological disorders and diseases, mitochondrial dysfunction has also been linked to many psychological disorders via cell disruption in areas of the brain important in cognitive function.

\section{Gene based therapeutic approaches}

Mutations in genes relating to proper mitochondrial function often lead to a decreased number of organelles which in turn results in lowered energy production and eventual cell death. Therapeutic approaches to combat mitochondrial impairment often focus around boosting the number of active mitochondria within a cell or increasing the activity of already present organelles, it has been found that mimicking starvation effectively inhibits disease by promoting this increased activity [116]. Targeting these pathways for therapeutic intervention may be achieved by increasing activity of upstream regulators of biogenesis such as the TOR pathway, Sirtuins, NAD+ boosters and AMPK [117-119] or by increasing activity of downstream effectors of biogenesis such as TFAM, PGC-1 $a$ and NRF-1 [120]. The most understood pharmacological agents from these pathways are the SIRT1 


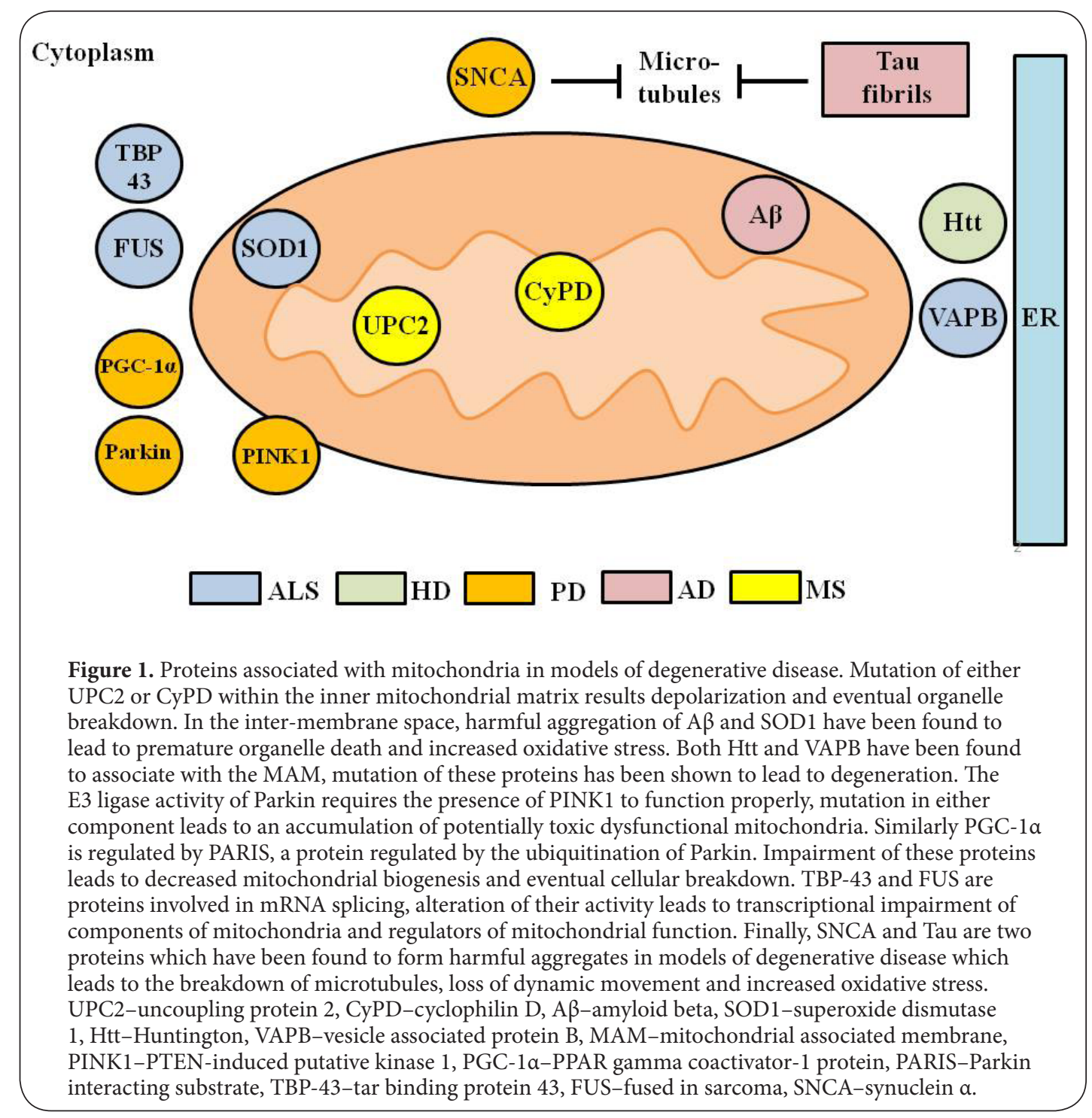

agonists SRT1720 and SRT 2104 both of which have been shown to increase lifespan in mice [121]. Future studies into SIRT1 agonists may lead to new pharmacological treatments for mitochondrial disease but no current clinical study has shown a positive effect in human hosts.

\section{Conclusions}

Mitochondria are essential cellular organelles that when damaged can lead to grave and often irreversible cellular consequences. They are related to or are affected by the consequences of all age-related degenerative disorders and may impact the pathogenesis of many non-age related disorders through their function as energy providers and protectors against oxidative stress. Many diseases related to mitochondrial dysfunction have therapies that target the symptoms rather than the cause of disease itself, leading to a diminished quality of life and lower life expectancy among patients. A number of these approaches have sought to prevent mitochondrial degeneration as a method of controlling disease, but due to the dynamic and complex multifunctional nature of the organelle, many have yet to demonstrate significant in vivo results. Future drug development and disease models should look to advance upon the knowledge gained from these previous efforts. An important next step in creating models of mitochondrial disease is to determine specific mechanisms of oxidative damage, or specific triggers for cell death cascades and whether or not these are conserved between distinct causes of pathogenesis. Figure 1 shows that many of these diseases share pathways of pathology or commonly disrupted genes, comparing and contrasting these genes may lead to a pathway of regulation involving specific targetable genes to combat 
Merzetti and Staveley Neuroscience Discovery 2013,

mitochondrial dysfunction across a broad range of disease. References

List of abbreviations

AD: Alzheimer Disease

AIF: Apoptosis inducing factor

ALS: Amyotrophic Lateral Sclerosis

AMD: Age Related Macular Degeneration

Apaf1: Apoptotic protease-activating factor 1

ATP: Adenosine Triphosphate

Cy PD: Cyclophilin D

ER: Endoplasmic Reticulum

ETC: Electron Transport Chain

FADH: Flavin Adenine Hydrogen Di-nucleotide

FUS: Fused in Sarcoma

HD: Huntington Disease

KSS: Kearns-Sayre Syndrome

LHON: Leher's Hereditary Optic Neuropathy

MAM: Mitochondria Associated Membrane

MPT: Mitochondrial Permeability Transition

MS: Multiple Sclerosis

NADH: Nicotinamide Adenine Dinucleotide

PD: Parkinson Disease

PINK1: PTEN Induced Kinase 1

REDOX: Reduction-Oxidation

ROS: Reactive Oxygen Species

s-IBM: Sporadic Inclusion-body Myositis

Sp1: Specificity 1 human transcription factor

TCA: Tricarboxylic Acid Cycle

TDP-43: TAR DNA Binding Protein

TFAM: Mitochondrial Transcription Factor A

UPC2: Mitochondria Uncoupling Protein 2

VAPB: Vesicle-associated Membrane Protein B

\section{Competing interests}

The authors declare that they have no competing interests.

\section{Authors' contributions}

\begin{tabular}{|l|c|c|}
\hline Authors' contributions & EMM & BES \\
\hline Research concept and design & $\checkmark$ & $\checkmark$ \\
\hline Collection and/or assembly of data & -- & -- \\
\hline Data analysis and interpretation & -- & -- \\
\hline Writing the article & $\checkmark$ & $\checkmark$ \\
\hline Critical revision of the article & $\checkmark$ & $\checkmark$ \\
\hline Final approval of article & $\checkmark$ & $\checkmark$ \\
\hline Statistical analysis & -- & -- \\
\hline
\end{tabular}

\section{Acknowledgement}

The research of the authors has been supported by Memorial University School of Graduate Studies funding to EMM and Natural Sciences and Engineering Research Council of Canada (NSERC) Canada Discovery Grants and Parkinson Society Canada Pilot Project Grants including from the Fond Saucier-Van Berkom-Parkinson Society Quebéc and Parkinson Society Newfoundland and Labrador to BES.

\section{Publication history}

EIC: Tadanori Tomita, Northwestern University Feinberg School of Medicine, USA.

Received: 29-Jul-2013 Revised: 06-Sep-2013

Accepted: 09-Oct-2013 Published: 23-Oct-2013
1. Karbowski M and Neutzner A. Neurodegeneration as a consequence of failed mitochondrial maintenance. Acta Neuropathol. 2012; 123:15771. | Article | PubMed

2. Huang $\mathrm{H}$ and Manton $\mathrm{KG}$. The role of oxidative damage in mitochondria during aging: a review. Front Biosci. 2004; 9:1100-17. | Article | PubMed

3. Margulis L. The origin of plant and animal cells. Am Sci. 1971; 59:2305. | Article | PubMed

4. Yang D, Oyaizu Y, Oyaizu H, Olsen GJ and Woese CR. Mitochondrial origins. Proc Natl Acad Sci U S A. 1985; 82:4443-7. | Article | PubMed Abstract | PubMed Full Text

5. Yamauchi A. Rate of gene transfer from mitochondria to nucleus: effects of cytoplasmic inheritance system and intensity of intracellular competition. Genetics. 2005; 171:1387-96. | Article | PubMed Abstract I PubMed Full Text

6. DiMauro $S$ and Schon EA. Mitochondrial respiratory-chain diseases. $N$ Engl J Med. 2003; 348:2656-68. | Article | PubMed

7. J. L. Popot and C. de Vitry: On the microassembly of integral membrane proteins. Annu Rev Biophys Biophys Chem 1990, 19:369403. | Article | PubMed

8. Allen JF. Control of gene expression by redox potential and the requirement for chloroplast and mitochondrial genomes. J Theor Biol. 1993; 165:609-31. | Article | PubMed

9. Lehninger A. Receptor biophysics and biochemistry. Mitochondria. Neurosci Res Program Bull. 1973; 11:185-92. | PubMed

10. Rigoulet $M$, Yoboue ED and Devin A. Mitochondrial ROS generation and its regulation: mechanisms involved in $\mathrm{H}(2) \mathrm{O}(2)$ signaling. Antioxid Redox Signal. 2011; 14:459-68. | Article | PubMed

11. Koopman WJ, Nijtmans LG, Dieteren CE, Roestenberg P, Valsecchi F, Smeitink JA and Willems PH. Mammalian mitochondrial complex I: biogenesis, regulation, and reactive oxygen species generation. Antioxid Redox Signal. 2010; 12:1431-70. | Article | PubMed

12. Christianson DW. Structural chemistry and biology of manganese metalloenzymes. Prog Biophys Mol Biol. 1997; 67:217-52. | Article | PubMed

13. I. Fridovich: Superoxide radical and superoxide dismutases. Annu Rev Biochem 1995, 64:97-112. | Article | PubMed

14. Miriyala S, Spasojevic I, Tovmasyan A, Salvemini D, Vujaskovic Z, St Clair $D$ and Batinic-Haberle I. Manganese superoxide dismutase, MnSOD and its mimics. Biochim Biophys Acta. 2012; 1822:794-814. | Article | PubMed Abstract | PubMed Full Text

15. Lenaz G. Mitochondria and reactive oxygen species. Which role in physiology and pathology? Adv Exp Med Biol. 2012; 942:93-136. Article | PubMed

16. Barja G. Oxygen radicals, a failure or a success of evolution? Free Radic Res Commun. 1993; 18:63-70. | Article | PubMed

17. Foreman J, Demidchik V, Bothwell JH, Mylona P, Miedema H, Torres MA, Linstead P, Costa S, Brownlee C, Jones JD, Davies JM and Dolan L. Reactive oxygen species produced by NADPH oxidase regulate plant cell growth. Nature. 2003; 422:442-6. | Article | PubMed

18. Sauer H, Rahimi G, Hescheler J and Wartenberg M. Role of reactive oxygen species and phosphatidylinositol 3-kinase in cardiomyocyte differentiation of embryonic stem cells. FEBS Lett. 2000; 476:218-23. | Article | PubMed

19. Gechev TS and Hille J. Hydrogen peroxide as a signal controlling plant programmed cell death. J Cell Biol. 2005; 168:17-20. | Article | PubMed Abstract | PubMed Full Text

20. Blackwell KA, Sorenson JP, Richardson DM, Smith LA, Suda O, Nath $\mathrm{K}$ and Katusic $\mathrm{ZS}$. Mechanisms of aging-induced impairment of endothelium-dependent relaxation: role of tetrahydrobiopterin. Am J Physiol Heart Circ Physiol. 2004; 287:H2448-53. | Article | PubMed

21. Uldry M, Yang W, St-Pierre J, Lin J, Seale $P$ and Spiegelman BM. Complementary action of the PGC-1 coactivators in mitochondrial 
Merzetti and Staveley Neuroscience Discovery 2013,

biogenesis and brown fat differentiation. Cell Metab. 2006; 3:333-41. | Article | PubMed

22. Andersson U and Scarpulla RC. Pgc-1-related coactivator, a novel, serum-inducible coactivator of nuclear respiratory factor 1-dependent transcription in mammalian cells. Mol Cell Biol. 2001; 21:3738-49. | Article | PubMed Abstract | PubMed Full Text

23. Ongwijitwat $S$ and Wong-Riley $M T$. Is nuclear respiratory factor $\mathbf{2}$ a master transcriptional coordinator for all ten nuclear-encoded cytochrome c oxidase subunits in neurons? Gene. 2005; 360:65-77. | Article I PubMed

24. Bras M, Queenan B and Susin SA. Programmed cell death via mitochondria: different modes of dying. Biochemistry (MOSC). 2005; 70:231-9. | Article | PubMed

25. Cande C, Cecconi F, Dessen P and Kroemer G. Apoptosis-inducing factor (AIF): key to the conserved caspase-independent pathways of cell death? J Cell Sci. 2002; 115:4727-34. | Article | PubMed

26. Oltvai $\mathrm{ZN}$, Milliman $\mathrm{CL}$ and Korsmeyer $\mathrm{SJ}$. Bcl-2 heterodimerizes in vivo with a conserved homolog, Bax, that accelerates programmed cell death. Cell. 1993; 74:609-19. | Article | PubMed

27. Chipuk JE and Green DR. How do BCL-2 proteins induce mitochondrial outer membrane permeabilization? Trends Cell Biol. 2008; 18:157-64. | Article | PubMed Abstract | PubMed Full Text

28. Shore GC. Apoptosis: it's BAK to VDAC. EMBO Rep. 2009; 10:1311-3. I Article | PubMed Abstract | PubMed Full Text

29. Elgass K, Pakay J, Ryan MT and Palmer CS. Recent advances into the understanding of mitochondrial fission. Biochim Biophys Acta. 2013; 1833:150-61. | Article | PubMed

30. Friedman JR, Lackner LL, West M, DiBenedetto JR, Nunnari J and Voeltz GK. ER tubules mark sites of mitochondrial division. Science. 2011; 334:358-62. | Article | PubMed Abstract | PubMed Full Text

31. Yoneda M, Miyatake T and Attardi G. Complementation of mutant and wild-type human mitochondrial DNAs coexisting since the mutation event and lack of complementation of DNAs introduced separately into a cell within distinct organelles. Mol Cell Biol. 1994; 14:2699-712. | Article | PubMed Abstract | PubMed Full Text

32. Rambold AS, Kostelecky B, Elia N and Lippincott-Schwartz J. Tubular network formation protects mitochondria from autophagosomal degradation during nutrient starvation. Proc Natl Acad Sci U S A. 2011; 108:10190-5. | Article | PubMed Abstract | PubMed Full Text

33. Lindner AB, Madden R, Demarez A, Stewart EJ and Taddei F. Asymmetric segregation of protein aggregates is associated with cellular aging and rejuvenation. Proc Natl Acad Sci U S A. 2008; 105:3076-81. | Article | PubMed Abstract | PubMed Full Text

34. Hollenbeck PJ and Saxton WM. The axonal transport of mitochondria. J Cell Sci. 2005; 118:5411-9. | Article | PubMed Abstract | PubMed Full Text

35. Ohno N, Kidd GJ, Mahad D, Kiryu-Seo S, Avishai A, Komuro H and Trapp BD. Myelination and axonal electrical activity modulate the distribution and motility of mitochondria at CNS nodes of Ranvier. J Neurosci. 2011; 31:7249-58. | Article | PubMed Abstract | PubMed Full Text

36. Wu LL and Zhou XF. Huntingtin associated protein 1 and its functions. Cell Adh Migr. 2009; 3:71-6. | Article I PubMed Abstract | PubMed Full $\underline{\text { Text }}$

37. Costanzo $M$ and Zurzolo $C$. The cell biology of prion-like spread of protein aggregates: mechanisms and implication in neurodegeneration. Biochem J. 2013; 452:1-17. | Article | PubMed

38. Goedert $M$ and Spillantini MG. A century of Alzheimer's disease. Science. 2006; 314:777-81. | Article | PubMed

39. Jayadev S, Leverenz JB, Steinbart E, Stahl J, Klunk W, Yu CE and Bird TD. Alzheimer's disease phenotypes and genotypes associated with mutations in presenilin 2. Brain. 2010; 133:1143-54. | Article | PubMed Abstract | PubMed Full Text

40. Goedert M, Jakes R, Spillantini MG, Crowther RA, Cohen P, Vanmechelen E, Probst A, Gotz J and Burki K. Tau protein in Alzheimer's disease. Biochem Soc Trans. 1995; 23:80-5. | Pdf |
PubMed

41. Wright AF, Goedert $M$ and Hastie ND. Familial Alzheimer's disease. Beta amyloid resurrected. Nature. 1991; 349:653-4. | Article | PubMed

42. Gotz J and Ittner LM. Animal models of Alzheimer's disease and frontotemporal dementia. Nat Rev Neurosci. 2008; 9:532-44. | Article I PubMed

43. Hardy JA and Higgins GA. Alzheimer's disease: the amyloid cascade hypothesis. Science. 1992; 256:184-5. | Article | PubMed

44. Rhein V, Song X, Wiesner A, Ittner LM, Baysang G, Meier F, Ozmen L, Bluethmann H, Drose S, Brandt U, Savaskan E, Czech C, Gotz J and Eckert A. Amyloid-beta and tau synergistically impair the oxidative phosphorylation system in triple transgenic Alzheimer's disease mice. Proc Natl Acad Sci U S A. 2009; 106:20057-62. | Article | PubMed Abstract | PubMed Full Text

45. Dragicevic N, Mamcarz M, Zhu Y, Buzzeo R, Tan J, Arendash GW and Bradshaw PC. Mitochondrial amyloid-beta levels are associated with the extent of mitochondrial dysfunction in different brain regions and the degree of cognitive impairment in Alzheimer's transgenic mice. J Alzheimers Dis. 2010; 20 Suppl 2:S535-50. | Article | PubMed

46. Anantharaman M, Tangpong J, Keller JN, Murphy MP, Markesbery WR, Kiningham KK and St Clair DK. Beta-amyloid mediated nitration of manganese superoxide dismutase: implication for oxidative stress in a APPNLH/NLH X PS-1P264L/P264L double knock-in mouse model of Alzheimer's disease. Am J Pathol. 2006; 168:1608-18. | Article | PubMed Abstract | PubMed Full Text

47. Area-Gomez E, Del Carmen Lara Castillo M, Tambini MD, GuardiaLaguarta C, de Groof AJ, Madra M, Ikenouchi J, Umeda M, Bird TD, Sturley SL and Schon EA. Upregulated function of mitochondriaassociated ER membranes in Alzheimer disease. EMBO J. 2012; 31:4106-23. | Article | PubMed Abstract | PubMed Full Text

48. Moreira PI, Santos MS and Oliveira CR. Alzheimer's disease: a lesson from mitochondrial dysfunction. Antioxid Redox Signal. 2007; 9:162130. | Article | PubMed

49. Hudson G, Sims R, Harold D, Chapman J, Hollingworth P, Gerrish A, Russo G, Hamshere M, Moskvina V, Jones N, Thomas C, Stretton A, Holmans PA, O'Donovan MC, Owen MJ, Williams J and Chinnery PF. No consistent evidence for association between mtDNA variants and Alzheimer disease. Neurology. 2012; 78:1038-42. | Article | PubMed Abstract | PubMed Full Text

50. Lew M. Overview of Parkinson's disease. Pharmacotherapy. 2007; 27:155S-160S. | Article | PubMed

51. Wirdefeldt K, Adami HO, Cole P, Trichopoulos D and Mandel J. Epidemiology and etiology of Parkinson's disease: a review of the evidence. Eur J Epidemiol. 2011; 26 Suppl 1:S1-58. | Article | PubMed

52. Olanow $\mathrm{CW}$ and McNaught K. Parkinson's disease, proteins, and prions: milestones. Mov Disord. 2011; 26:1056-71. | Article | PubMed

53. Bekris LM, Mata IF and Zabetian CP. The genetics of Parkinson disease. J Geriatr Psychiatry Neurol. 2010; 23:228-42. | Article | PubMed Abstract | PubMed Full Text

54. Lin MT, Cantuti-Castelvetri I, Zheng K, Jackson KE, Tan YB, Arzberger T, Lees AJ, Betensky RA, Beal MF and Simon DK. Somatic mitochondrial DNA mutations in early Parkinson and incidental Lewy body disease. Ann Neurol. 2012; 71:850-4. | Article | PubMed Abstract | PubMed Full $\underline{\text { Text }}$

55. Kim HY, Heise H, Fernandez CO, Baldus $M$ and Zweckstetter M. Correlation of amyloid fibril beta-structure with the unfolded state of alpha-synuclein. Chembiochem. 2007; 8:1671-4. | Article | PubMed

56. Liu G, Zhang C, Yin J, Li X, Cheng F, Li Y, Yang H, Ueda K, Chan P and Yu $S$. alpha-Synuclein is differentially expressed in mitochondria from different rat brain regions and dose-dependently down-regulates complex I activity. Neurosci Lett. 2009; 454:187-92. | Article | PubMed

57. Narendra D, Tanaka A, Suen DF and Youle RJ. Parkin is recruited selectively to impaired mitochondria and promotes their autophagy. J Cell Biol. 2008; 183:795-803. | Article | PubMed Abstract | PubMed Full Text

58. J. C. Greene, A. J. Whitworth, I. Kuo, L. A. Andrews, M. B. Feany and L. J. Pallanck: Mitochondrial pathology | Article | PubMed Abstract | 
PubMed Full Text and apoptotic muscle degeneration in Drosophila parkin mutants. Proc Natl Acad Sci U S A 2003, 100:4078-83. | Article | PubMed Abstract I PubMed Full Text

59. Koh $\mathrm{H}$ and Chung J. PINK1 and Parkin to control mitochondria remodeling. Anat Cell Biol. 2010; 43:179-84. | Article | PubMed Abstract | PubMed Full Text

60. Yang $Y$, Gehrke $S$, Imai $Y$, Huang $Z$, Ouyang $Y$, Wang JW, Yang L, Beal MF, Vogel $\mathrm{H}$ and Lu B. Mitochondrial pathology and muscle and dopaminergic neuron degeneration caused by inactivation of Drosophila Pink1 is rescued by Parkin. Proc Natl Acad Sci U S A. 2006; 103:10793-8. | Article | PubMed Abstract | PubMed Full Text

61. Castillo-Quan JI. Parkin' control: regulation of PGC-1alpha through PARIS in Parkinson's disease. Dis Model Mech. 2011; 4:427-9. | Article | PubMed Abstract | PubMed Full Text

62. Shin JH, Ko HS, Kang H, Lee Y, Lee YI, Pletinkova O, Troconso JC, Dawson VL and Dawson TM. PARIS (ZNF746) repression of PGC-1alpha contributes to neurodegeneration in Parkinson's disease. Cell. 2011; 144:689-702. | Article | PubMed Abstract | PubMed Full Text

63. Engel WK and Askanas V. Inclusion-body myositis: clinical, diagnostic, and pathologic aspects. Neurology. 2006; 66:S20-9. | Article | PubMed

64. Askanas V, Engel WK and Nogalska A. Pathogenic considerations in sporadic inclusion-body myositis, a degenerative muscle disease associated with aging and abnormalities of myoproteostasis. $J$ Neuropathol Exp Neurol. 2012; 71:680-93. | Article | PubMed

65. Douglas PM and Cyr DM. Interplay between protein homeostasis networks in protein aggregation and proteotoxicity. Biopolymers 2010; 93:229-36. | Article | PubMed Abstract | PubMed Full Text

66. Fratta P, Engel WK, McFerrin J, Davies KJ, Lin SW and Askanas V. Proteasome inhibition and aggresome formation in sporadic inclusion-body myositis and in amyloid-beta precursor proteinoverexpressing cultured human muscle fibers. Am J Pathol. 2005; 167:517-26. | Article | PubMed Abstract | PubMed Full Text

67. Nixon RA and Yang DS. Autophagy failure in Alzheimer's disease-locating the primary defect. Neurobiol Dis. 2011; 43:38-45. | Article | PubMed Abstract | PubMed Full Text

68. Howitz KT, Bitterman KJ, Cohen HY, Lamming DW, Lavu S, Wood JG, Zipkin RE, Chung P, Kisielewski A, Zhang LL, Scherer B and Sinclair DA. Small molecule activators of sirtuins extend Saccharomyces cerevisiae lifespan. Nature. 2003; 425:191-6. | Article | PubMed

69. Wang D, Wang J, Bonamy GM, Meeusen S, Brusch RG, Turk C, Yang P and Schultz PG. A small molecule promotes mitochondrial fusion in mammalian cells. Angew Chem Int Ed Engl. 2012; 51:9302-5. | Article I PubMed

70. Zhao Q, Wang J, Levichkin IV, Stasinopoulos S, Ryan MT and Hoogenraad NJ. A mitochondrial specific stress response in mammalian cells. EMBO J. 2002; 21:4411-9. | Article | PubMed Abstract | PubMed Full Text

71. Haynes $C M$ and Ron $D$. The mitochondrial UPR - protecting organelle protein homeostasis. J Cell Sci. 2010; 123:3849-55. I Article I PubMed

72. Nargund AM, Pellegrino MW, Fiorese CJ, Baker BM and Haynes CM. Mitochondrial import efficiency of ATFS-1 regulates mitochondrial UPR activation. Science. 2012; 337:587-90. | Article | PubMed Abstract I PubMed Full Text

73. Karpinska A and Gromadzka G. [Oxidative stress and natural antioxidant mechanisms: the role in neurodegeneration. From molecular mechanisms to therapeutic strategies]. Postepy Hig Med Dosw (Online). 2013; 67:43-53. | Article | PubMed

74. Vonsattel JP and DiFiglia M. Huntington disease. J Neuropathol Exp Neurol. 1998; 57:369-84. | Article | PubMed

75. Squitieri F, Cannella M, Sgarbi G, Maglione V, Falleni A, Lenzi P, Baracca A, Cislaghi G, Saft C, Ragona G, Russo MA, Thompson LM, Solaini $G$ and Fornai $F$. Severe ultrastructural mitochondrial changes in lymphoblasts homozygous for Huntington disease mutation. Mech Ageing Dev. 2006; 127:217-20. | Article | PubMed

76. Browne SE, Bowling AC, MacGarvey U, Baik MJ, Berger SC, Muqit MM, Bird ED and Beal MF. Oxidative damage and metabolic dysfunction in
Huntington's disease: selective vulnerability of the basal ganglia. Ann Neurol. 1997; 41:646-53. | Article | PubMed

77. Stack EC and Ferrante RJ. Huntington's disease: progress and potential in the field. Expert Opin Investig Drugs. 2007; 16:1933-53. | Article | PubMed

78. Powers WJ, Videen TO, Markham J, McGee-Minnich L, Antenor-Dorsey $\mathrm{JV}$, Hershey T and Perlmutter JS. Selective defect of in vivo glycolysis in early Huntington's disease striatum. Proc Natl Acad Sci U S A. 2007; 104:2945-9. | Article | PubMed Abstract | PubMed Full Text

79. Dunah AW, Jeong H, Griffin A, Kim YM, Standaert DG, Hersch SM, Mouradian MM, Young AB, Tanese N and Krainc D. Sp1 and TAFII130 transcriptional activity disrupted in early Huntington's disease. Science. 2002; 296:2238-43. | Article | PubMed

80. Chaturvedi RK, Adhihetty P, Shukla S, Hennessy T, Calingasan N, Yang L, Starkov A, Kiaei M, Cannella M, Sassone J, Ciammola A, Squitieri F and Beal MF. Impaired PGC-1alpha function in muscle in Huntington's disease. Hum Mol Genet. 2009; 18:3048-65. | Article | PubMed Abstract | PubMed Full Text

81. Chang DT, Rintoul GL, Pandipati S and Reynolds IJ. Mutant huntingtin aggregates impair mitochondrial movement and trafficking in cortical neurons. Neurobiol Dis. 2006; 22:388-400. | Article | PubMed

82. B. M. Keegan and J. H. Noseworthy: Multiple sclerosis. Annu Rev Med 2002, 53:285-302.

83. Keegan BM and Noseworthy JH. Multiple sclerosis. Annu Rev Med. 2002; 53:285-302. | Article | PubMed

84. Lu F, Selak M, O'Connor J, Croul S, Lorenzana C, Butunoi C and Kalman B. Oxidative damage to mitochondrial DNA and activity of mitochondrial enzymes in chronic active lesions of multiple sclerosis J Neurol Sci. 2000; 177:95-103. | Article | PubMed

85. Slee M, Finkemeyer J, Krupa M, Raghupathi R, Gardner J, Blumbergs $P$, Agzarian $M$ and Thyagarajan D. A novel mitochondrial DNA deletion producing progressive external ophthalmoplegia associated with multiple sclerosis. J Clin Neurosci. 2011; 18:1318-24. | Article | PubMed

86. Stys PK, Waxman SG and Ransom BR. Ionic mechanisms of anoxic injury in mammalian CNS white matter: role of $\mathrm{Na}+$ channels and $\mathrm{Na}(+)-\mathrm{Ca2}+$ exchanger. J Neurosci. 1992; 12:430-9. | Article | PubMed

87. Young EA, Fowler CD, Kidd GJ, Chang A, Rudick R, Fisher E and Trapp $\mathrm{BD}$. Imaging correlates of decreased axonal $\mathrm{Na}+/ \mathrm{K}+\mathrm{ATPase}$ in chronic multiple sclerosis lesions. Ann Neurol. 2008; 63:428-35. | Article | PubMed

88. Forte M, Gold BG, Marracci G, Chaudhary P, Basso E, Johnsen D, Yu X, Fowlkes J, Rahder M, Stem K, Bernardi P and Bourdette D. Cyclophilin $D$ inactivation protects axons in experimental autoimmune encephalomyelitis, an animal model of multiple sclerosis. Proc Natl Acad Sci U S A. 2007; 104:7558-63. | Article | PubMed Abstract | PubMed Full Text

89. Ferguson B, Matyszak MK, Esiri MM and Perry VH. Axonal damage in acute multiple sclerosis lesions. Brain. 1997; 120 ( Pt 3):393-9. | Article | PubMed

90. Cozzolino M, Ferri A, Valle C and Carri MT. Mitochondria and ALS: implications from novel genes and pathways. Mol Cell Neurosci. 2013; 55:44-9. | Article | PubMed

91. Magrane J, Sahawneh MA, Przedborski S, Estevez AG and Manfredi G. Mitochondrial dynamics and bioenergetic dysfunction is associated with synaptic alterations in mutant SOD1 motor neurons. J Neurosci. 2012; 32:229-42. | Article | PubMed Abstract | PubMed Full Text

92. Bergemalm D, Jonsson PA, Graffmo KS, Andersen PM, Brannstrom T, Rehnmark A and Marklund SL. Overloading of stable and exclusion of unstable human superoxide dismutase-1 variants in mitochondria of murine amyotrophic lateral sclerosis models. J Neurosci. 2006; 26:4147-54. | Article | PubMed

93. Cozzolino M, Pesaresi MG, Amori I, Crosio C, Ferri A, Nencini M and Carri MT. Oligomerization of mutant SOD1 in mitochondria of motoneuronal cells drives mitochondrial damage and cell toxicity. Antioxid Redox Signal. 2009; 11:1547-58. | Article | PubMed 
Merzetti and Staveley Neuroscience Discovery 2013,

94. De Vos KJ, Morotz GM, Stoica R, Tudor EL, Lau KF, Ackerley S, Warley A, Shaw CE and Miller CC. VAPB interacts with the mitochondrial protein PTPIP51 to regulate calcium homeostasis. Hum Mol Genet. 2012; 21:1299-311. | Article | PubMed Abstract | PubMed Full Text

95. Polymenidou M, Lagier-Tourenne C, Hutt KR, Huelga SC, Moran J, Liang TY, Ling SC, Sun E, Wancewicz E, Mazur C, Kordasiewicz H, Sedaghat Y, Donohue JP, Shiue L, Bennett CF, Yeo GW and Cleveland DW. Long pre-mRNA depletion and RNA missplicing contribute to neuronal vulnerability from loss of TDP-43. Nat Neurosci. 2011; 14:459-68. | Article | PubMed Abstract | PubMed Full Text

96. Guo W, Chen Y, Zhou X, Kar A, Ray P, Chen X, Rao EJ, Yang M, Ye H, Zhu L, Liu J, Xu M, Yang Y, Wang C, Zhang D, Bigio EH, Mesulam M, Shen Y, $\mathrm{Xu} \mathrm{Q}$, Fushimi $\mathrm{K}$ and $\mathrm{Wu} J \mathrm{~J}$. An ALS-associated mutation affecting TDP43 enhances protein aggregation, fibril formation and neurotoxicity. Nat Struct Mol Biol. 2011; 18:822-30. | Article | PubMed Abstract | PubMed Full Text

97. Braun RJ, Sommer C, Carmona-Gutierrez D, Khoury CM, Ring J, Buttner $S$ and Madeo F. Neurotoxic 43-kDa TAR DNA-binding protein (TDP-43) triggers mitochondrion-dependent programmed cell death in yeast. $J$ Biol Chem. 2011; 286:19958-72. | Article | PubMed Abstract | PubMed Full Text

98. Xu YF, Gendron TF, Zhang YJ, Lin WL, D'Alton S, Sheng H, Casey MC, Tong J, Knight J, Yu X, Rademakers R, Boylan K, Hutton M, McGowan E, Dickson DW, Lewis J and Petrucelli L. Wild-type human TDP43 expression causes TDP-43 phosphorylation, mitochondrial aggregation, motor deficits, and early mortality in transgenic mice. J Neurosci. 2010; 30:10851-9. | Article | PubMed Abstract | PubMed Full Text

99. Tradewell ML, Yu Z, Tibshirani M, Boulanger MC, Durham HD and Richard S. Arginine methylation by PRMT1 regulates nuclearcytoplasmic localization and toxicity of FUS/TLS harbouring ALS-linked mutations. Hum Mol Genet. 2012; 21:136-49. | Article | PubMed

100. Artuso L, Zoccolella S, Favia P, Amati A, Capozzo R, Logroscino G, Serlenga L, Simone I, Gasparre G and Petruzzella V. Mitochondrial genome aberrations in skeletal muscle of patients with motor neuron disease. Amyotroph Lateral Scler Frontotemporal Degener. 2013; 14:261-6. | Article | PubMed

101. Jarrett SG, Lin H, Godley BF and Boulton ME. Mitochondrial DNA damage and its potential role in retinal degeneration. Prog Retin Eye Res. 2008; 27:596-607. | Article | PubMed

102. Huoponen K. Leber hereditary optic neuropathy: clinical and molecular genetic findings. Neurogenetics. 2001; 3:119-25. | Article | PubMed

103. Harvey JN and Barnett D. Endocrine dysfunction in Kearns-Sayre syndrome. Clin Endocrinol (Oxf). 1992; 37:97-103. | Article I PubMed

104. Soga F, Ueno $S$ and Yorifuji S. [Deletions of mitochondrial DNA in Kearns-Sayre syndrome]. Nihon Rinsho. 1993; 51:2386-90. | Article | PubMed

105. Carelli V, Ross-Cisneros FN and Sadun AA. Optic nerve degeneration and mitochondrial dysfunction: genetic and acquired optic neuropathies. Neurochem Int. 2002; 40:573-84. | Article | PubMed

106. Hoegger MJ, Lieven CJ and Levin LA. Differential production of superoxide by neuronal mitochondria. BMC Neurosci. 2008; 9:4. | Article | PubMed Abstract | PubMed Full Text

107. Kong GY, Van Bergen NJ, Trounce IA and Crowston JG. Mitochondrial dysfunction and glaucoma. J Glaucoma. 2009; 18:93-100. | Article | PubMed

108. Ju WK, Liu Q, Kim KY, Crowston JG, Lindsey JD, Agarwal N, Ellisman MH, Perkins GA and Weinreb RN. Elevated hydrostatic pressure triggers mitochondrial fission and decreases cellular ATP in differentiated RGC-5 cells. Invest Ophthalmol Vis Sci. 2007; 48:2145-51. | Article | PubMed

109. Liu Q, Ju WK, Crowston JG, Xie F, Perry G, Smith MA, Lindsey JD and Weinreb RN. Oxidative stress is an early event in hydrostatic pressure induced retinal ganglion cell damage. Invest Ophthalmol Vis Sci. 2007; 48:4580-9. | Article | PubMed
110. Abu-Amero KK, Morales J and Bosley TM. Mitochondrial abnormalities in patients with primary open-angle glaucoma. Invest Ophthalmol Vis Sci. 2006; 47:2533-41. | Article | PubMed

111. Fine SL, Berger JW, Maguire MG and Ho AC. Age-related macular degeneration. N Engl J Med. 2000; 342:483-92. | Article | PubMed

112. Decanini A, Nordgaard CL, Feng X, Ferrington DA and Olsen TW. Changes in select redox proteins of the retinal pigment epithelium in age-related macular degeneration. Am J Ophthalmol. 2007; 143:60715. | Article | PubMed Abstract | PubMed Full Text

113. Moreira PI, Santos MS, Seica R and Oliveira CR. Brain mitochondrial dysfunction as a link between Alzheimer's disease and diabetes. J Neurol Sci. 2007; 257:206-14. | Article | PubMed

114. Jackson AC, Kammouni W and Fernyhough P. Role of oxidative stress in rabies virus infection. Adv Virus Res. 2011; 79:127-38. | Article | PubMed

115. Wallace DC. Mitochondria and cancer. Nat Rev Cancer. 2012; 12:68598. I Article I PubMed

116. Fontana $L$, Partridge $L$ and Longo VD. Extending healthy life span-from yeast to humans. Science. 2010; 328:321-6. | Article | PubMed Abstract | PubMed Full Text

117. Houtkooper RH, Pirinen E and Auwerx J. Sirtuins as regulators of metabolism and healthspan. Nat Rev Mol Cell Biol. 2012; 13:225-38. I Article I PubMed

118. Pan $Y$, Nishida $Y$, Wang $M$ and Verdin E. Metabolic regulation, mitochondria and the life-prolonging effect of rapamycin: a minireview. Gerontology. 2012; 58:524-30. | Article | PubMed

119. Hardie DG, Ross FA and Hawley SA. AMP-activated protein kinase: a target for drugs both ancient and modern. Chem Biol. 2012; 19:122236. | Article | PubMed

120. Vina J, Gomez-Cabrera MC, Borras C, Froio T, Sanchis-Gomar F, Martinez-Bello VE and Pallardo FV. Mitochondrial biogenesis in exercise and in ageing. Adv Drug Deliv Rev. 2009; 61:1369-74. | Article I PubMed

121. Yu W, Wan Z, Qiu XF, Chen Y and Dai YT. Resveratrol, an activator of SIRT1, restores erectile function in streptozotocin-induced diabetic rats. Asian J Androl. 2013; 15:646-51. | Article | PubMed

\section{Citation:}

Merzetti EM and Staveley BE. Mitochondrial dynamics in degenerative disease and disease models. Neurosci Discov. 2013; 1:8.

http://dx.doi.org/10.7243/2052-6946-1-8 